\title{
Usefulness of cytological evaluation of milk in diagnosing mastitis in bitches
}

\author{
IOSIF VASIU, FLAVIU TĂBĂRAN*, RAUL ALEXANDRU POP**, \\ FLORENTIN GHEORGHE BRUDAŞCĂ ${ }^{\star * *}$, ASTA TVARIJONAVICIUTE****, \\ ROMAN DAZBROWSKI*****
}

\begin{abstract}
Department of Infectious Disease, *Department of Pathology and Forensic Medicine, **Department of Obstetrics and Gynecology, ${ }^{* *}$ Department of Infectious Disease, Faculty of Veterinary Medicine, University of Agricultural Science and Veterinary Medicine Cluj-Napoca, Romania ****Interlab-UMU, Regional Campus of International Excellence "Mare Nostrum", University of Murcia, Spain

*****Department and Clinic of Animal Reproduction, Faculty of Veterinary Medicine, University of Life Sciences, Głęboka 30, 20-612 Lublin, Poland
\end{abstract}

Vasiu I., Tăbăran F., Pop R. A., Brudaşcă F. G., Tvarijonaviciute A., Dąbrowski R. Usefulness of cytological evaluation of milk in diagnosing mastitis in bitches

Summary

The aim of this study was to evaluate the prevalence of mastitis in female lactating dogs by interpreting the milk cytology in the diagnostic protocol. Milk samples were manually collected in sterile vials from 89 lactating bitches (i.e., 157 mammary glands) aged between 10 and 168 months. Milk smears were obtained by using the squash and May-Grünwald-Giemsa (MGG) techniques. Acute mastitis episodes were consistent with increased numbers of degenerated neutrophils, erythrocytes, and engulfed bacteria. Eosinophils were present in retention mastitis inflammations. Foamy cells were present in every type of inflammation. Subclinical cases of mastitis were characterized by a reduced number of neutrophils with engulfed bacteria. The period of lactation has a great influence on the type of mastitis encountered. Our results have showed that the lactation period has influence over different types of mammary gland inflammations. In most cases, galactostasis (65\%) followed by subclinical mastitis $(22 \%)$ and acute mastitis $(13 \%)$ were encountered. Neutrophils and phagocytosis exhibited specificity for acute inflammations, whereas eosinophils and foamy cells were consistent with cases of retention mastitis. The presence of red blood cells in most cases was correlated with acute inflammations. It seems that cytological evaluation of milk could be quite helpful in diagnosing mammary gland inflammations.

Keywords: female dogs, mastitis, inflammation, milk cytology

One of the most common disturbances noticed during the lactation period in female dogs is mastitis, which is described as an inflammation of the mammary glands accompanied by milk stasis in glandular tissue (18). For bitches with mastitis, the main risk is represented by an increased rate in the percentage of offspring mortality. Milk cytology comes to the aid of diagnostic protocol, treatment strategy, and illness prognostic $(8,15)$. Milk smears obtained during the course of septic mammary glands - with the presence of erythrocytes, degenerated neutrophils, activated macrophages and phagocytosis - are consistent with acute inflammation episodes $(1,12)$. Parasitical and retention mastitis of female dogs also develop an inflammatory response with the presence of an increased number of foamy cells (12) and eosinophils (9). In anteand postpartum lactating bitches, the prevalence of mastitis acuta is thought to be around $23 \%$ and $54.2 \%$, respectively (6). In bitches with pseudopregnancy the prevalence of acute mastitis is estimated to be around $27 \%$ (6). In the antepartum period the prevalence of subclinical mastitis is $54.2 \%$, followed by a $23.9 \%$ prevalence in the postpartum period and $21.9 \%$ due to pseudopregnancy (6).

The aim of this study was to characterize variations in milk cytology collected from female dogs, in contrast with each type of inflammation encountered in the lactating mammary glands of both gestating and nongestating dams. Moreover, the current research also aimed to establish the prevalence of bitch mastitis according to the evaluation of milk cytology. 


\section{Material and methods}

A total of 89 female dogs admitted at the Department and Clinic of Reproduction, Obstetrics and Gynecology, Faculty of Veterinary Medicine, University of Agricultural Science and Veterinary Medicine, Cluj-Napoca, Romania were included in the study. Dogs classified into the study consisted of 29 different breeds (American Staffordshire Terrier, Basset Hound, Beagle, Bichon, Boxer, German Shorthaired Pointer, American Bulldog, English Bulldog, French Bulldog, Cane Corso, Caucasian Shepherd Dog, Bucovina Shepherd Dog, Central Asian Shepherd Dog, German Shepherd, Belgian Shepherd, Cocker Spaniel, Doberman Pinscher, Golden Retriever, Siberian Husky, Labrador Retriever, Neapolitan Mastiff, Pekingese, Rottweiler, Saint Bernard, Shih Tzu, Dachshund, Vizsla, Yorkshire Terrier, and mongrel), of different parity (43 multiparous bitches, 32 primiparous, 9 intact females, and there was no data for the remaining 5), of various ages (between 12 and 168 months), and varying body sizes (between 3 and $65 \mathrm{~kg}$; mean $29.38 \mathrm{~kg}$ ) with diagnosed clinical or subclinical mastitis. A total of $4 \%$ of bitches were in the antepartum period, $80 \%$ were in the postpartum period and $16 \%$ were females with pseudopregnancy. The dogs participated in an investigation of milk and an assessment of serum C-reactive protein (CRP) level [published earlier (19)].

Clinical mastitis was considered present if bitches presented mastitis gangrenosa $(\mathrm{n}=1)$, mastitis acuta $(\mathrm{n}=12)$, mammae congestion $(\mathrm{n}=3)$, or galactostasis $(\mathrm{n}=12)$. Clinical cases of mastitis were diagnosed based on the presence of hypothermia, hyperthermia, dehydration, tacky mucous membranes, delayed capillary refill time, sepsis, overt signs of mammary illness such as hardened, engorged, painful mammary glands with or without a modified mammary gland secretion or with or without natimortality, and failure of puppies to thrive alongside other assays such as milk $\mathrm{pH}$, milk cytology, and CRP levels in both milk and serum (19).

Diagnosis of subclinical mastitis cases $(\mathrm{n}=17)$ was based on the history, clinical examination alongside abovementioned assays.

Mastitis acuta $(\mathrm{n}=12)$, including Mastitis gangrenosa $(\mathrm{n}=1)$, was characterized by the presence of fever $\left(40-41^{\circ} \mathrm{C}\right)$ and hypertrophy of the mammary gland. Moreover, in all cases, extremely painful, hot, swollen mammary tissues, anorexia, and pyrexia were observed. Blood examination revealed neutrophilia with a left shift, alongside elevated levels of CRP in both milk $(6.5 \mu \mathrm{g} / \mathrm{ml})$ and serum $(7.1 \mu \mathrm{g} /$ $\mathrm{ml}$ ) for cases of mastitis acuta. For mastitis gangrenosa females, milk CRP levels were also elevated in both the milk $(8.0 \mu \mathrm{g} / \mathrm{ml})$ and serum $(113.4 \mu \mathrm{g} / \mathrm{ml})$ of the tested samples (19).

Mammae congestion $(\mathrm{n}=3)$ was diagnosed by clinical evaluation of local signs of mastitis such as painful mammary glands without inflammatory cells, and phagocytosis on milk smears, alongside an acidic milk $\mathrm{pH}$ reaction (below $6.5)$ and elevated levels of milk $(1.7 \mu \mathrm{g} / \mathrm{ml})$ and serum (11.4 $\mu \mathrm{g} / \mathrm{ml}$ ) CRP (19).

Galactostasis $(\mathrm{n}=12)$ was diagnosed mainly in females with pseudopregnancy, which in most cases were asymptomatic and had no signs of infection or other symptoms compatible with the pathology. It was diagnosed by the presence of distended, warm, painful mammary glands with obstruction of milk flow through the nipples. In all the cases, milk $\mathrm{pH}$ was $>7$, even reaching a value up to 9.5 , with elevated values of CRP, in both milk $(6.3 \mu \mathrm{g} / \mathrm{ml})$ and blood $(14.6 \mu \mathrm{g} / \mathrm{ml})(19)$.

Subclinical cases $(\mathrm{n}=12)$ of mastitis were diagnosed based on the clinical examination, medical history, and an additional test that showed the presence of an alkaline $\mathrm{pH}$ (over 7) of milk alongside cytological examination, and high levels of serum $(21.9 \mu \mathrm{g} / \mathrm{ml})$ and milk $(11.3 \mu \mathrm{g} / \mathrm{ml})$ CRP (19).

A total of 157 milk samples were collected (in the range of 0.5-4 $\mathrm{ml}$ for individual samples) from the lactating bitches. From these samples, 7 (4\%) were from dogs at antepartum period, $127(81 \%)$ were from dogs in their postpartum period, and $23(15 \%)$ from bitches with pseudopregnancy.

For the antepartum period, milk was collected in the last week before parturition, while for the postpartum period milk was harvested between the first and the sixth week of postpartum. Because it was very difficult for owners to estimate when galactorrhea started for dams with pseudopregnancy, this data was not recorded.

Milk samples were manually collected in sterile vials (Nunc ${ }^{\mathrm{TM}}$, Waltham, USA), by using sterile gloves after a thorough cleaning of the mammary glands with $70 \%$ alcohol and rushed to the Infectious Disease Department at the University of Agricultural Science and Veterinary Medicine Cluj-Napoca for immediate testing. Samples were centrifuged for 10 minutes at $2500 \mathrm{rpm}$. After centrifugation, from the obtained sediments, milk smears were obtained by using the "squash" and MGG (E. Merck, Darmstadt, Germany) techniques (11). Six of the samples were not interpreted due to dye flaws.

Frequency, prevalence, and its $95 \%$ confidence intervals (CI) of antepartum, postpartum and diagnostics of Lactatio sine graviditate (lactation without pregnancy) mammary glands were assessed. The differences were considered significant if $p \leq 0.05$. Data analysis was performed using EpiInfo 7 software (CDC, USA).

All experimental protocols and procedures were approved by a local Ethics Committee for Animal Experimentation of University of Agricultural Science and Veterinary Medicine, Cluj-Napoca, Romania.

\section{Results and discussion}

Cytological differences were observed between healthy and inflamed mammae. Clinically healthy mammary glands were characterized by the presence of somatic cells, accompanied by a high amount of cellular debris, many squamous epithelial cells (Fig. 1), few neutrophils, macrophages, erythrocytes, and foamy cells.

In dams with mammae congestion, few numbers of somatic cells, accompanied by increased numbers of cellular debris (Fig. 2), few neutrophils, inactivated macrophages, and epithelial cells were spotted on milk smears.

In subclinical mastitis, somatic cells were moderate to high, accompanied by slightly elevated numbers 


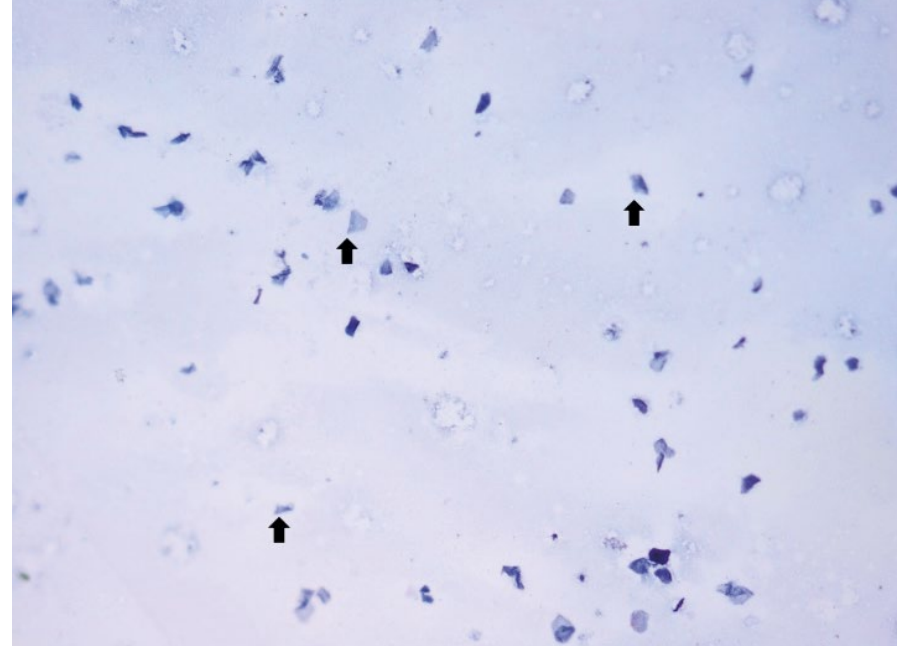

Fig. 1. Presence of many squamouse epithelial cells on a basophilic background (black arrows) $($ MGG, $\times 10)$

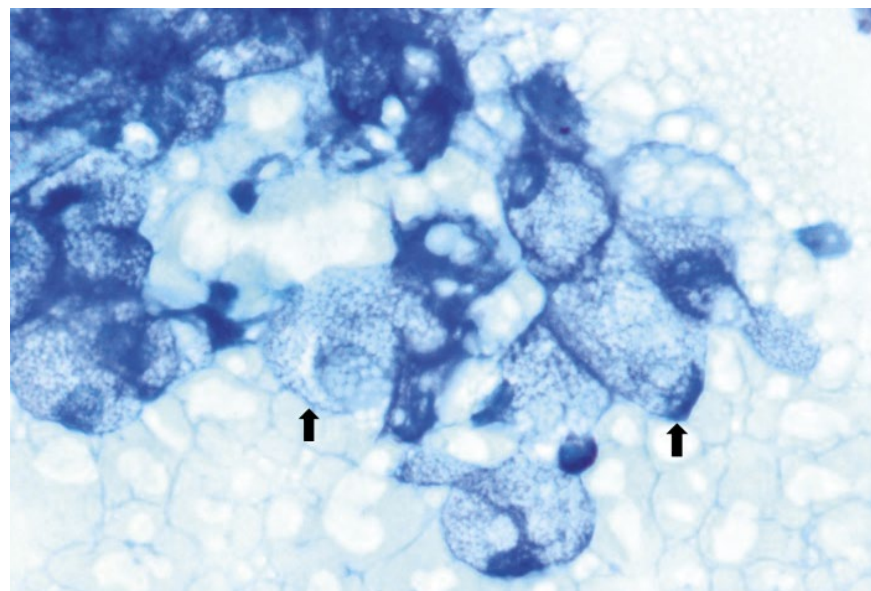

Fig. 3. Presence of agglutinated foamy cells on a vacuolar background (black arrows) (MGG, × 100)

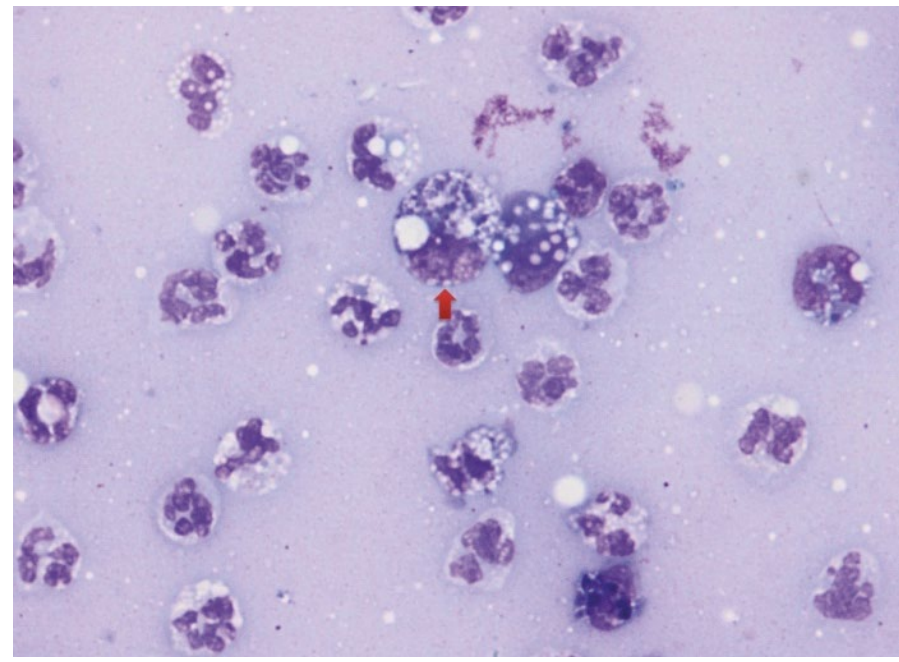

Fig. 5. Presence of many neutrophils (black arrow) and foamy cells (red arrow) on a basophilic background with discrete lipid droplets (MGG, × 100)

of degenerated neutrophils, many foamy (Fig. 3) and epithelial cells along with activated macrophages,



Fig. 2. Presence of cellular debris on a basophilic background (red arrow) with variable sized lipid droplets (black arrow) (MGG, $\times$ 40)



Fig. 4. Presence of eosinophils (red arrow), erythrocytes and foamy cells (black arrow) with hemosiderin phagocytosis (arrow head) (MGG, × 100)

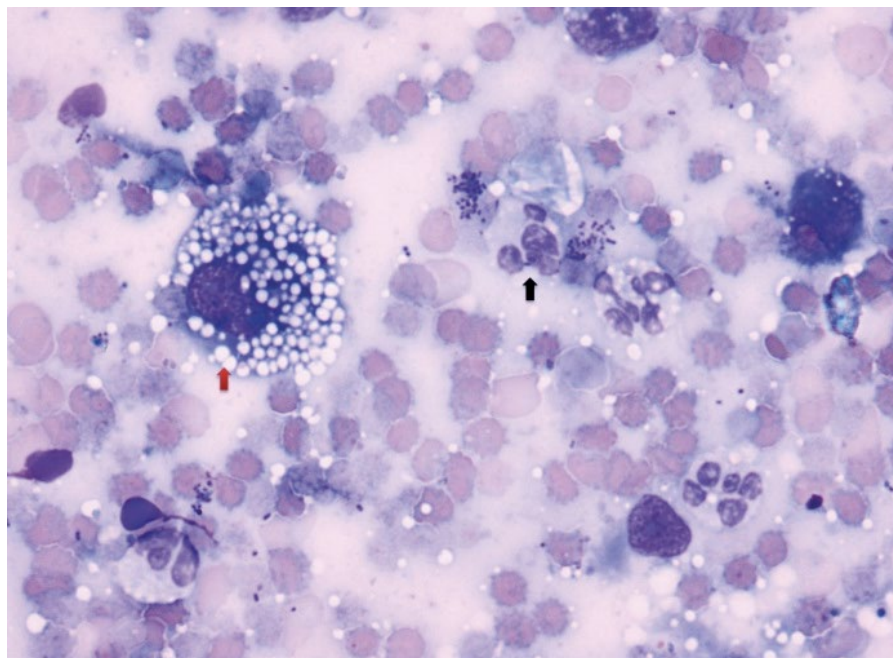

Fig. 6. Presence of foamy cells (red arrow), erythrocytes and degenerated neutrophils with bacterial phagocytosis (black arrow) on an eosinophilic, vacuolar background (MGG, $\times 100$ )

bacteria, and phagocytosis. Scattered cellular debris, erythrocytes, and eosinophils were also encountered. 


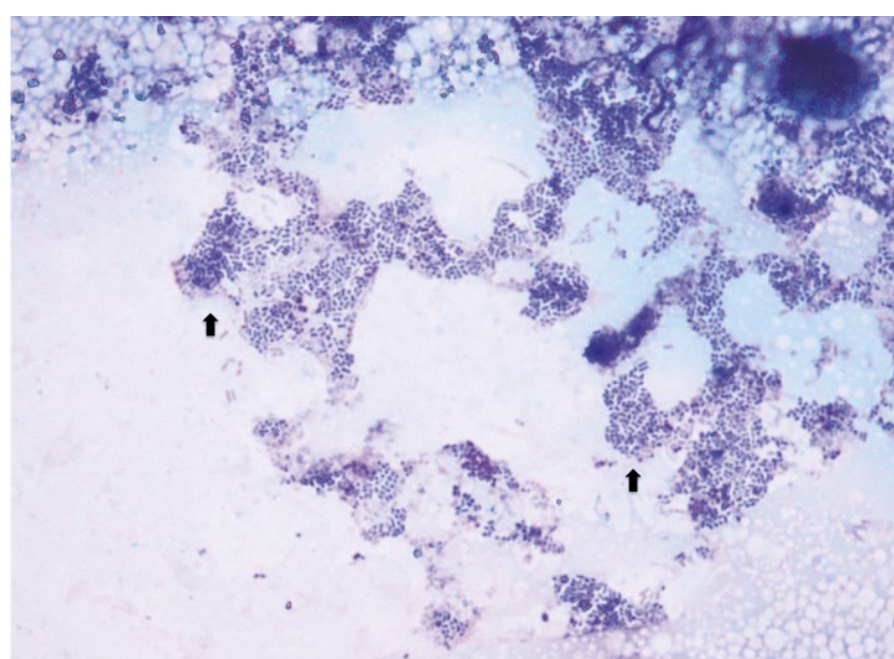

Fig. 7. Presence of cluster organised round shaped bacteria (black arrow) on a milk smear from a septic mammary gland $($ MGG, $\times$ 100)

Episodes of galactostasis were characterized by the presence of somatic cells. On milk smears, epithelial cells, eosinophils (Fig. 4), activated macrophages, foamy cells, and degenerated neutrophils, accompanied by bacteria and phagocytosis, were the dominant features. Cellular debris and erythrocytes had also been identified.

Episodes of mastitis acuta (including mastitis gangrenosa) were characterized by an increased number of foamy cells, degenerated neutrophils (Fig. 5), cellular debris, and bacteria accompanied by phagocytosis (Figs 6-8). The presence of small numbers of activated macrophages, eosinophils, and erythrocytes were also encountered.

The diagnostic prevalence, according to each specific lactation period with $95 \% \mathrm{CI}$ in 157 mammary glands from 89 lactating dams, was included in Table 1.

Galactostasis was more frequent in females with pseudopregnancy $(65 \%)$ than in postpartum $(5 \%)$ and antepartum $(14 \%)$ bitches. Mastitis acuta was encountered in the same proportions in both pseudopregnancy $(13 \%)$ and postpartum (13\%) dams, but in a higher proportion $(29 \%)$ in females at their antepartum period. Subclinical episodes were more frequent in females with postpartum $(22 \%)$ than in females with Lactatio sine graviditate $(4 \%)$. In females in their antepartum (57\%) and postpartum $(52 \%)$ period, more healthy mammary glands were found then in dams with pseudopregnancy $(9 \%)$.

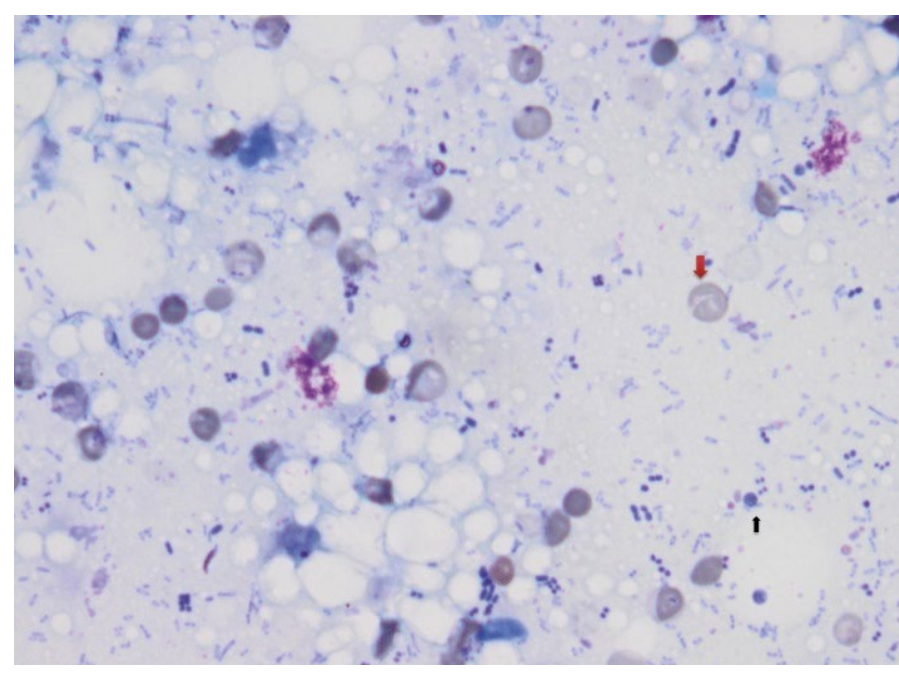

Fig. 8. Presence of erythrocytes (red arrow), cell debris and many rod-shaped or round bacteria (black arrows) in a milk sample from a septic mammary gland $(\mathrm{MGG}, \times 100)$

In the ante-partum period 57\% (4/7, CI 95\%: 18.41-90.10) of the tested samples were from healthy mammary glands, 29\% (2/7, CI 95\%: 3.67-70.96) were diagnosed with mastitis acuta while 14\% (1/7, CI 95\%: $0.36-57.87)$ of the tested mammae were with retention mastitis (Tab. 1).

From females with the postpartum period, $52 \%$ (66/127, CI 95\%: 42.93\%-60.91\%) of the tested mammary glands were clinically healthy, $22 \%(28 / 127$, CI 95\%: 15.18-30.26) were diagnosed with subclinical mastitis, 13\% (17/127, CI 95\%: 8.00-20.56) were diagnosed with mastitis acuta, 5\% (6/127, CI 95\%: 1.75-10.00) were diagnosed with retention mastitis,

Tab. 1. Bitch mastitis diagnostic prevalence according to each specific lactation period with $\mathbf{9 5 \%}$ confidence intervals (CI) in 157 mammary glands from 89 lactating dams

\begin{tabular}{|c|c|c|c|c|c|c|}
\hline \multirow{3}{*}{$\begin{array}{l}\text { Mammary } \\
\text { gland health } \\
\text { status }\end{array}$} & \multicolumn{6}{|c|}{ Lactation period } \\
\hline & \multicolumn{2}{|c|}{ Ante-partum } & \multicolumn{2}{|c|}{ Post-partum } & \multicolumn{2}{|c|}{ Lactatio sine graviditate } \\
\hline & $n_{1}(\%)$ & $95 \% \mathrm{Cl}$ & $n_{1}(\%)$ & $95 \% \mathrm{CI}$ & $n_{1}(\%)$ & $95 \% \mathrm{Cl}$ \\
\hline HM & $4(57)$ & $18.41-90.10$ & $66(52)$ & $42.93-60.91$ & $2(9)$ & $1.070-28.04$ \\
\hline MC & & & $5(4)$ & $0.86-7.87$ & & \\
\hline SM & & & $28(22)$ & $15.18-30.26$ & $1(4)$ & $0.11-21.95$ \\
\hline MA & $2(29)$ & $3.67-70.96$ & $17(13)$ & $8.00-20.56$ & $3(13)$ & $2.78-33.59$ \\
\hline MG & & & $1(1)$ & $0.02-4.31$ & & \\
\hline RM & 1 (14) & $0.36-57.87$ & $6(5)$ & $1.75-10.00$ & $15(65)$ & 42.7-83.63 \\
\hline I & & & $4(3)$ & $0.86-7.87$ & $2(9)$ & $1.07-28.04$ \\
\hline Overall & $7(4)$ & & $127(81)$ & & $23(15)$ & \\
\hline
\end{tabular}

Explanations: $\mathrm{HM}=$ healthy mammary glands, $\mathrm{MC}=$ mammary congestion, $\mathrm{SM}=$ subclinical mastitis, $\mathrm{MA}=$ mastitis acuta, $\mathrm{MG}=$ mastitis gangrenosa, $\mathrm{RM}=$ retention mastitis, $\mathrm{I}=$ inappropriate, $\mathrm{n}_{1}=$ number of lactating mammary glands. In the ante-partum period, the highest percentage of acute mastitis $(29 \%)$ was found, followed by retention mastitis (14\%), the remaining (57\%) mammary glands were healthy. In the post-partum period the highest percentage of subclinical mastitis $(22 \%)$ was found, followed by acute mastitis $(13 \%)$, retention mastitis $(5 \%)$ mammary congestion $(4 \%)$ and finally gangrenous mastitis $(1 \%)$, the rest of the mammary glands $(52 \%)$ were healthy. In females with Lactatio sine graviditate, the highest percentage of mammary gland inflammatory pathology was represented by retention mastitis $(65 \%)$ followed by acute mastitis $(13 \%)$ and subclinical mastitis $(4 \%)$, while in this category, a list of healthy mammary glands $(9 \%)$ were encountered. 
4\% (5/127, CI 95\%: 1.29-8.95) were diagnosed with mammary congestion, 3\% (4/127, CI 95\%: 0.86\%-7.87\%) of the samples were inappropriate for interpretation, and only $1 \%(1 / 127, \mathrm{CI}$ 95\%: 0.02-4.31) of the tested mammary glands were diagnosed with mastitis gangrenosa (Tab. 1).

From dams with Lactatio sine graviditate, $65 \%$ (15/23, CI 95\%: 42.7-83.63) were diagnosed with retention mastitis, 13\% (3/23, CI 95\%: 2.78-33.59) were diagnosed with mastitis acuta, 4\% (1/23, CI 95\%: 0.11-21.95)

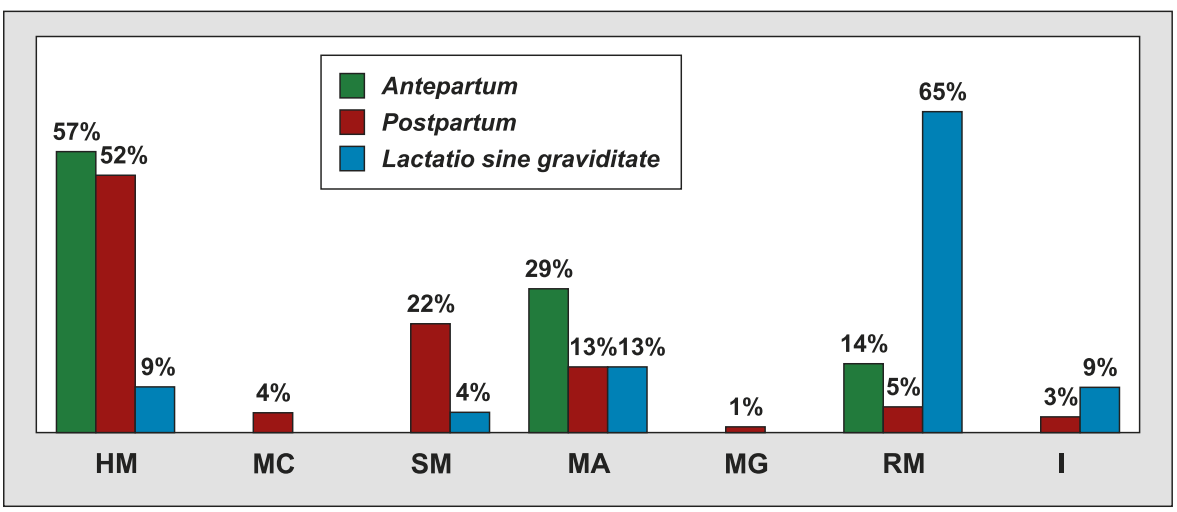

Fig. 9. Mammary gland diagnostic prevalence during postpartum period Explanations: as in Tab. 1.

were diagnosed with subclinical mastitis, $9 \%(2 / 23, \mathrm{CI}$ 95\%: 1.07-28.04) were inappropriate for interpretation, and only $9 \%(2 / 23$, CI 95\%: $1.07-28.04)$ of the tested mammary glands were clinically healthy (Tab. 1).

In bitches, the lactation period has great influence on the different types of mammary gland inflammations $(\mathrm{p}<0.05)$ (Fig. 9).

Diagnosing canine mastitis is of high clinical importance, since it may lead to sepsis in lactating females (1). Even though in the past years $(3,19)$ efforts have been made to find a non invasive method to diagnose mastitis episodes in bitches early, for a quick diagnostics cytology is still the primary tool available for physicians (15). As the Romanowsky-type stains are rapid and easy to perform, they have widely spread among practitioners, based on their daily use, and thereby they have become a quick and precise diagnostic tool (11). Quite recently, milk cytology was used to differentiate mammary gland lesions, whether inflammatory, hyperplastic or neoplastic type (15).

In our study it was shown that during the inflammation of glandula mammae in female dogs macrophages and lymphocytes were noticed in milk smears. These results were similar to our previous study where milk cytology assays showed the presence of inflammatory cells of a bitch in the course of mastitis acuta (20). The presence of inflammatory cells like macrophages and lymphocytes highlights the important role of these cells in the local defense mechanisms (13). Macrophages and lymphocytes are predominant in the canine mammae, constituting a resident cell population in the mucosa and they also participate in the removal of fat droplets and protein micelles (13). According to some authors (4), bitch milk cytology lacks any clinical significance. This hypothesis is in contrast with other authors, whose findings show that milk cell count increases during bitch mammary gland inflammations (16). Furthermore, experimental papers (21) showed that $12 \mathrm{~h}$ after bacterial challenge, neutrophils and activated macrophages are spotted on milk smears, while somatic cell counts stay high throughout lactation. In milk from mammary glands of control animals, the values of inflammatory cells were also increased $12 \mathrm{~h}$ after challenge (21).
Moreover, degenerated neutrophils with engulfed bacteria were also noticed in our study in the course of septic mastitis. These results were similar with the studies performed by Olson and Sangha (12, 15). Foamy cells and reduced numbers of segmented neutrophils were also present in the milk of healthy mammary glands (12). Numerous degenerated neutrophils, scattered ductal cells, and necrotic material have been found on milk smears in human specimens, as a response to the breast inflammation (7).

Eosinophils have been noted in cases of infrequently milked mammary glands (12) and parasitical mammary infections (9). In our study, eosinophils were consistently encountered in smears from mammary glands with retention mastitis. They were also spotted in a few cases of subclinical mastitis and mastitis acuta episodes. Clinical presentation of the bitch (i.e., presence of Lactatio sine graviditate) alongside the presence of eosinophils on milk smears are key features in differentiating the subclinical from retention mastitis episodes.

The presence of bacteria on milk smears from healthy mammary glands may have resulted from skin contamination, unless germs were accompanied by phagocytosis and an increased number of degenerated neutrophils (12). Martín et al. proved that lactobacilli are part of the normal canine milk flora, and thus explained the lack of any inflammatory response on some smears where bacteria were spotted (10).

Our results contradiction the findings of Jung et al. for postpartum mastitis acuta and pseudopregnancy dams, as well as for subclinical mastitis episodes from females with pseudopregnancy. These authors indicate higher percentages for these mastitis episodes. However, for antepartum mastitis acuta and Lactatio sine graviditate subclinical mastitis cases (6), the obtained results in previous studies were the same as in this present study. In cases of milk retention, or unusual engorgement of mammary glands with milk, as seen in cows (17), bitches become sensitized to the casein from their own milk. An increased pressure in the mammary gland will result in prolonged contact of casein with the blood stream (17), and thus will stimulate the production of biogenic amines such as histamine and 
serotonin and the chemotactic eosinophilic factor by basophils and mast cells, generating a type I hypersensitivity reaction (2). These mechanisms can explain the presence of eosinophils in undrained mammary glands (galactostasis) such as pseudopregnancy, retention mastitis, and infrequently milked mammae due to small litters. In such cases, bitch mammae might suffer a type I local hypersensitivity.

Mammary congestion, which has also been mistaken for agalactia, should also be accounted into differential diagnosis of mastitis, since this condition often occurs in mothers that are excellent heavy milk producers. Because of sudden copious production of milk at first letdown, especially in the inguinal mammary glands, the glandular tissue gets heavily congested. In such cases, there is no evidence of milk bacterial pathogens and the mammae are warm and painful with transient hypothermia. Failure to recognize and deal with mammary congestion results either in drying off the most heavily producing glands with consequent lactation loss or in a second bacterial invasion causing mastitis (5).

In order to avoid indiscriminate use of antibiotics, treatment should at least be based on an initial cytological examination of milk samples from affected mammary glands (8). Cytology should still be interpreted with caution, because of the low numbers of polymorphonuclear leukocytes that are normally found on milk smears from healthy mammary glands. However, a large number of degenerated neutrophils with engulfed bacteria are consistent with infection (12). Because apoptotic bodies (14) and lactobacilli are normally found in canine milk (10), efforts should be made to differentiate between self and non-self cells.

In conclusion, the obtained data from the present study suggest that cytological evaluation of milk could be quite helpful in diagnosing mammary gland inflammations. It can also help clinicians to confirm the presence of clinical mastitis, and avoid agalactia in the most developed mammary glands, as well as secondary bacterial infections in infrequently milked mammary glands.

\section{References}

1. Biddle D., Macintire D. K.: Obstetrical emergencies. Clin. Tech. Small Anim. Pract. 2000, 15, 88-93.

2. Day J. M. (ed.): Clinical Immunology of the Dog and Cat, Manson Publishing/ The Veterinary Press, London 2008, p. 11-59.

3.Dzieciot M., Stefaniak T., Twardon J., Kozdrowski R.: Wybrane wskazniki mleka i krwi suk ze zdrowym i chorym gruczolem sutkowym (in Polish), [Chosen parameters of the milk and blood of bitches with healthy mammary glands and those suffering from mastitis], Med. Weter. 2006, 62, 59-61.

4. Fontaine E., Tanneur M. L., Josein A.: Mammite gangreneuse chez la chienne reproductrice (in French). Le point Vétérinaire 2007, 276, 25-29.

5. Jones E. D., Joshua O. J. (eds): Reproductive Clinical Problems in the Dog, Wright PSG, Bristol 1988, p. 113-123.

6. Jung C., Wehrend A., König A., Bostedt H.: Investigations about the incidence, differentiation and microbiology of canine mastitis (in German). Prakt. Tierarzt 2002, 83, 508-511.

7. Koss L. G., Melamed M. R.: The breast, [in:] Koss L. G., Melamed M. R. (eds): Diagnostic Cytology and its Histopatologic Base. Lippincott Williams \& Wilkins, Baltimore 2006, p. 1082-1147.
8. Lopate C. (ed.): Management of Pregnant and Neonatal Dogs, Cats and Exotic Pets, Willey-Blackwell, Iowa 2012, p. 25-41.

9. Manuali E., Eleni C., Giovaninni P., Costarelli S., Ciorba A.: Unusual finding in a nipple discharge of a female dog: dirofilariasis of the breast. Diagn. Cytopathol. 2004, 132, 108-109.

10. Martín R., Olivares M., Pérez M., Xaus J., Torre C., Fernández L., Rodríguez J. Identification and evaluation of the probiotic potential of lactobacilli isolated from canine milk. Vet. J. 2010, 185, 193-198.

11. Meyer J. D., Connolly S. L., Heng H. G.: The acquisition and management of cytology specimens, [in:] Meyer J. D., Connolly S. L., Heng H. G. (eds): Canine and Feline Cytology, a Color Atlas and Interpetation Guide. Saunders Elsevier, St Louis 2010, p. 1-15.

12. Olson N. P., Olson A. L.: Cytologic evaluation of canine milk. Vet. Med. Small Anim. Clin. 1984, 79, 641-646.

13. Orfanou D. C., Pourlis A., Ververidis H. N., Mavrogianni V. S., Taitzoglou I. A., Boscos C. M., Fthenakis G. C.: Histological features in the mammary glands of female dogs throughout lactation. Anat. Histol. Embryol. 2010, 39, 473-478.

14. Reece W. (ed.): Functional Anatomy and Physiology of Domestic Animals Lippincott Williams \& Wilkins, Baltimore 2005.

15. Sangha S., Singh A., Sood N. K., Gupta K.: Specificity and sensitivity of cytological techniques for rapid diagnosis of neoplastic and non-neoplastic lesions of canine mammary gland. Braz. J. Vet. Pathol. 2011, 4, 13-22.

16. Seweryn T., Boryczko Z.: Bacterial inflammation of mammary gland in the bitch (in Polish). Życie Wet. 2009, 84, 138-144

17. Tizard I.: Immunologic Diseases, [in:] The Merck Veterinary Manual. Whitehouse Station Merck and Co. Inc, New Jersey 2010, p. 741-756.

18. Trasch K., Wehrend A., Bostedt H.: Ultrasonographic description of canine mastitis. Vet. Radiol. Ultr. 2007, 48, 580-584.

19. Vasiu I., Dąbrowski R., Martinez-Subiela S, Ceron J. J., Wdowiak A., Pop Al. R., Brudaşcă F. Gh.: Milk C-reactive protein in canine mastitis, Vet. Immunol. Immunopathol. 2017, 186, 41-44

20. Vasiu I., Spînu M., Pop Al. R., Bedecean I., Sarpataki O., Brudașcă F. Gh.: Mastitis acuta in a Hungarian Viszla bitch, caused by a Staphylococcus intermedius infection. Rev. Rom. Med. Vet. 2015, 25, 51-54.

21. Ververidis H. N., Mavro Gianni V. S., Fragkou I. A., Orfanou D. C., Gougoulis D. A., Tzivara A., Gouletsou P. G., Athanasiou L., Boscos C. M., Fthenakis G. C.: Experimental Staphylococcal mastits in bitches: Clinical, bacteriological, cytological, haematological, and pathological features. Vet. Microbiol. 2007, 124, 95-106

Corresponding author: Raul Alexandru Pop DVM, PhD, Department of Obstetrics and Gynecology, Faculty of Veterinary Medicine, University of Agricultural Science and Veterinary Medicine Cluj-Napoca, Romania; e-mail: quantasbasset@yahoo.com 